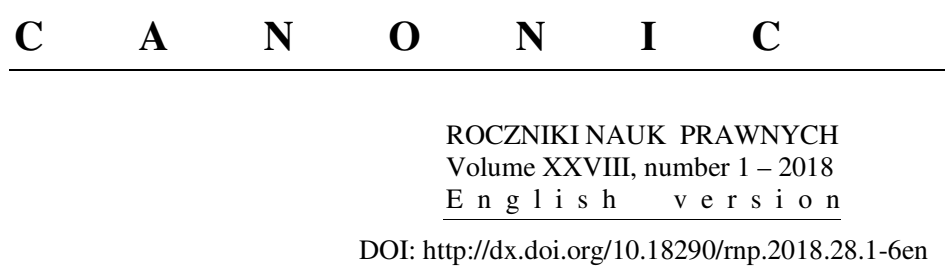

ANDRZEJ SZYMAŃSKI

\title{
THE CHURCH'S TEMPORAL GOODS IN THE WORK AND THE FINAL DOCUMENT DRAFTED BY THE FIRST SYNOD OF THE DIOCESE OF OPOLE
}

The Diocese of Opole, formally established by the Holy See on June 28, 1972 by the bull Episcoporum Polonia coetus, ${ }^{1}$ [also-A.S.] convened its synod, officially referred to as the "First Synod of the Diocese of Opole 2002-2005." The synod was the response of the diocesan community to the call of Pope John Paul II, who in his apostolic letter entitled Novo Millennio Ineunte $^{3}$ called on everyone to open confidently to the future which urgently needs to be "translated into the language of pastoral decisions and concrete programmes" according to the Gospel of Christ. ${ }^{4}$ The first synodal assembly of the particular Church of Opole, inaugurated by Archbishop Prof. Alfons

ANDRZEJ SZYMAŃSKI, PhD, Hab, is an associate professor at Opole University. He is the head of the Department of History of State and Law and Political-Legal Doctrines, Faculty of Law and Administration of Opole University; address ul. Katowicka 87a, 45-060 Opole, Poland; e-mail: szymanski.andrzej208@gmail.com

${ }^{1}$ A. SZYMAŃSKI, Ks. Bp dr Franciszek Jop-prawodawca i organizator diecezji opolskiej (Opole: Wydawnictwo Uniwersytetu Opolskiego, 2007), 22. However, a separate church administrative unit (Apostolic Administration of Opole Silesia) existed in the Opole region as early as on 15 August 1945.

${ }^{2}$ The synodal resolutions came into force on June 28, 2005.

${ }^{3}$ See John PaUl II, List apostolski Novo millennio ineunte (Kraków: Wydawnictwo Pallottinum, 2001).

${ }^{4}$ Telegram of April 2, 2002 sent to Holy Father John Paul II by Abp. Alfons Nossol on the occasion of the inauguration of the First Synod of the Diocese of Opole, Bulletin of the Synod of the Diocese of Opole [henceforth quoted as BSDO] 1 (2002): 2; letter of the Secretariat of State of the Holy See of April 30, 2002 on the occasion of the inauguration of the First Synod of the Diocese of Opole, BSDO 1 (2002): 2-3. 
Nossol, was a significant event in the ecclesiastical history of whole Opole Silesia, in harmony with the animated post-conciliar synodal movement in Poland. ${ }^{5}$

In the decree issued by Bishop of Opole No. 207/02/A on March 19, $2002,{ }^{6}$ convening the Synod, we find a statement saying that the goal of the Synod is to respond to the call of the Holy Father John Paul II to "sail out into the deep (Luke 5:4) and open confidently to the future which, having the Gospel of Jesus Christ in mind, we should translate into the language of decisions and concrete programs [...]."

The first Synod of Opole was primarily a pastoral synod. Its work focused on the parish, its needs, problems and pastoral possibilities. ${ }^{8}$ Here also lies the issue of material goods of the Church. The legal material concerning this subject area was provided by the church legislator in 10th (the last but one) chapter of the synodal statutes. ${ }^{9}$

On June 18, 2002, Archbishop Nossol, the Bishop of Opole, signed a decree establishing the composition of the Financial and Investment Commission of the Opole Synod. ${ }^{10}$ In this way, seventeen members and four consultors began to work on, among other things, diocesan regulations concerning

\footnotetext{
5 A. Szymański, “Pierwszy Synod Diecezji Opolskiej 2002-2005,” Studia Teologiczno-Historyczne Ślaska Opolskiego 28 (2008): 377.

${ }^{6}$ Decree of 19 March 2002 convening the First Synod of the Diocese of Opole [henceforth quoted as FSDO] and announcing its opening, No. 207/002/A, in Pierwszy Synod Diecezji Opolskiej (2002-2005). Statuty i Aneksy (Opole: Wydawnictwo Św. Krzyża, 2005), 311-13.

${ }^{7}$ A. SZYMAŃSKI, "Nauczanie i wychowanie chrześcijańskie w parafii w świetle uchwał I Synodu Diecezji Opolskiej," in Wychowanie religijne i moralne, ed. R. Sztychmiller and M. Różański (Olsztyn: Wydział Prawa i Administracji Uniwersytetu Warmińsko-Mazurskiego, 2015), 67-74.

${ }^{8}$ J. MikoŁaJec, "Duszpasterstwo rodzin w uchwałach Pierwszego Synodu Diecezji Opolskiej," Warszawskie Studia Pastoralne 3 (2006): 57.

${ }^{9}$ The FSDO final document (statutes) comprises 11 chapters: I. The parish as a venue where the Church and her mission are fulfilled; II. The parish in the church structures of the Diocese of Opole; III. Liturgical life in the parish; IV. Christian teaching and education in the parish; V. The vocation, formation and life of clerics; VI. The mission of the laity in the parish and in the family; VII. Concern for the Christian spirit of culture; VIII. The ecumenical dimension of parish life; IX. Parish charity work; X. The temporal goods in the service of the Church; XI. Final resolutions.

${ }^{10}$ Decree establishing the composition of the Financial and Investment Commission of the First Synod of the Diocese of Opole, BSDO 1 (2002): 32. The following became the Commission members: Fr Albert Glaeser-Chairman, Fr Walter Lenart-Secretary, Zdzisław Budziński (Opole), Jan Dudzik (Opole), Brygida Gruchot (Krapkowice), Józef Ibrom (Nysa), Marian Jagielski (Opole), Teresa Kierel (Zdzieszowice), Fr Waldemar Klinger (Winów), Fr Antoni Komor (Zdzieszowice), Fr Zygmunt Lubieniecki (Opole-Szczepanowice), Fr Ernest Noziński (Dziewkowice), Fr Tomasz Piontek (Racibórz), Sr Magdalena Skiera (Opole), Gabriela Szampera (Gogolin), Adam Szczegielniak (Opole), Fr Henry Wolf (Nysa). The consultors: Fr Andrzej Hanich (Opole), Fr Erwin Mateja (Kamień Śląski), Fr Paweł Stobrawa (Opole), and Fr Piotr Śnigórski (Nysa).
} 
the broadly defined material goods which are indispensable in the daily life of church communities.

The first significant record regarding the issues at hand, worked out by the relevant synodal commission, is the Working Paper of the synodal Financial and Investment Commission entitled The material goods of the Church of 2003. ${ }^{11}$ Of its two parts, the first one was intended to be discussed in the synodal groups, while the other one was a "working text addressed to Priests," in which the rules of remuneration and maintenance of clergy were discussed. ${ }^{12}$ The first part was quite faithfully reflected in the synodal statutes or relevant annexes, but the material issues of clerical persons were not. The other text addressing the subject of material goods in the particular Church of Opole is comprised of the synodal statutes of 2005 (including annexes) as the main outcome of the deliberations of the Opole Synod and its newly created particular law.

In this paper, due to the importance of the documents, I shall first analyse the content of the relevant synodal statutes and annexes, while the content of the working document will provide supplementary and comparative material. Proposals for the maintenance and remuneration of priests will be identified separately.

The Second Vatican Council teaches that Church estate is to be managed in such a way as to enable the Church's performance of its fundamental roles: proper worship, maintenance of clergy, charitable activity and apostolate. ${ }^{13}$ We need to realise that while the ministry of the Church has a supernatural purpose, material goods are necessary to provide that in this world. Therefore, it belongs to Church authorities to take care of the proper management of these goods. Dioceses, parishes and all other legal entities of the Church have the innate right to acquire, retain, administer, and alienate material goods for the purpose of conducting their religious mission independently of secular authority (st. 387).

\footnotetext{
${ }^{11}$ W drodze do Emaus. Dokumenty robocze Komisji Synodalnych (Opole: Wydawnictwo Św. Krzyża, 2003), 104ff.

${ }^{12}$ Ibid., 109-11.

${ }^{13}$ VATICAN II, Decretum de pastorali episcoporum munere in Ecclesia Christus Dominus, October 28, 1965, AAS 58 (1966), 673-96; Polish translation in VATICAN II, Konstytucje, dekrety, deklaracje, tekst polski, nowe ttumaczenie (Poznań: Pallottinum, 2002), 236-58. IDEM, Decretum de presbyterorum ministerio et vita Presbyterorum ordinis, December 7, 1965, AAS 58 (1966), 991-1024; Polish translation in VATICAN II, Konstytucje, dekrety, deklaracje, 478-508, no. 17.
} 
All transactions involving the temporal goods of the Church should be carried out in conformity with canons 1254 and 1260 of the 1983 Code of Canon Law,${ }^{14}$ therefore serving the goals of the Church. The accumulation of goods must proceed in compliance with the evangelical principle of the primacy of spiritual values (compare Matthew 16:26).

The faithful are obliged to assist the basic financial needs of the Church community in accordance with the prescripts of c. $222, \S 1 \mathrm{CIC} / 83 .{ }^{15} \mathrm{In}$ particular, sacred buildings, burial grounds and all other church property, movable and immovable, must be taken care of (st. 388).

\section{ADMINISTRATION OF THE TEMPORAL GOODS OF THE DIOCESE OF OPOLE}

Satisfaction of the duty of the Christian faithful to donate to the Church must be, however, proportional to individual capabilities ${ }^{16}$ which, according to the synodal fathers, "in many situations of today's world, are rather insignificant" (st. 389). However, "the needs of the Church and its institutions, including the needs of the most needy individuals, are considerable" (ibid.). The realization of the fifth Church commandment requires that the clergy and the faithful of the Opole diocese show "great sensitivity of conscience and openness to the needs of others" (ibid.). Those offerings which are essentially the "widow's mite" are particularly valuable if they come from a true heart.

\footnotetext{
${ }^{14}$ Codex Iuris Canonici auctoritate Ioannis Pauli PP. II promulgatus, January 25, 1983, AAS 75 (1983), pars II, 1-317; Polish translation in Kodeks Prawa Kanonicznego, translation approved by the Polish Episcopal Conference (Poznań: Pallottinum, 1984) [henceforth quoted as CIC/83]; the English version retrieved by Translator from www.vatican.va. See c. 1254 CIC/83: " $\$ 1$. To pursue its proper purposes, the Catholic Church by innate right is able to acquire, retain, administer, and alienate temporal goods independently from civil power. $\$ 2$. The proper purposes are principally: to order divine worship, to care for the decent support of the clergy and other ministers, and to exercise works of the sacred apostolate and of charity, especially toward the needy." C. $1260 \mathrm{CIC} / 83$ : "The Church has an innate right to require from the Christian faithful those things which are necessary for the purposes proper to it."

${ }^{15}$ See c. 222, §1 CIC/83: "The Christian faithful are obliged to assist with the needs of the Church so that the Church has what is necessary for divine worship, for the works of the apostolate and of charity, and for the decent support of ministers."

${ }^{16}$ Catechismus Catholicae Ecclesiae (Vatican City: Libreria Editrice Vaticana, 1997); Polish translation in Katechizm Kościoła Katolickiego, $2^{\text {nd }}$ ed. (Poznań: Pallottinum, 2012), no. 2043: "[...] the faithful also have the duty, each according to his or her abilities, to provide for the material needs of the Church."
} 
The assets of the Opole diocese are administered by the bishop of Opole, and on his behalf - in accordance with the relevant provisions of canon law-by the Finance Council and the diocesan finance officer established by him, the latter also being director of the Financial and Economic Department of the Diocesan Curia. He administers the material goods under the authority of the bishop, following strictly the guidelines of the Finance Council. ${ }^{17}$ Both the Council and the finance officer are guided by the provisions of canon law and the statute (st. 390). ${ }^{18}$

In order to create a solid material basis for the diocese, both clergy and the lay faithful must make appropriate contributions and give voluntary offerings. The task of pastors is to make the faithful more sensitive so that they will not forget this obligation, since it concerns both the particular and the universal Church. It lies within the bishop's discretion to order money collection and to burden church institutions and diocesan priests with contributions. These contributions and collections should be used to cover the expenses of diocesan institutions, and the bishop should hear the opinion of the Economic Council and the Presbyteral Council. In the Diocese of Opole,

${ }^{17}$ See c. $494, \S 3 \mathrm{CIC} / 83$ : "It is for the finance officer to administer the goods of the diocese under the authority of the bishop in accord with the budget determined by the finance council and, from the income of the diocese, to meet expenses which the bishop or others designated by him have legitimately authorized."

${ }^{18}$ See c. 492, CIC/83: " $\$ 1$. In every diocese a finance council is to be established, offer which the diocesan bishop himself or his delegate presides and which consists of at least three members of the Christian faithful truly expert in financial affairs and civil law, outstanding in integrity, and appointed by the bishop. $\S 2$. Members of the finance council are to be appointed for five years, but at the end of this period they can be appointed for other five year terms. §3. Persons who are related to the bishop up to the fourth degree of consanguinity or affinity are excluded from the finance council."

Compare c. 493 CIC/83: "In addition to the functions entrusted to it in Book V, The Temporal Goods of the Church, the finance council prepares each year, according to the directions of the diocesan bishop, a budget of the income and expenditures which are foreseen for the entire governance of the diocese in the coming year and at the end of the year examines an account of the revenues and expenses."

See also c. $494 \mathrm{CIC} / 83$ : " $\$ 1$. In every diocese, after having heard the college of consultors and the finance council, the bishop is to appoint a finance officer who is truly expert in financial affairs and absolutely distinguished for honesty. §2. The finance officer is to be appointed for a five year term but can be appointed for other five year terms at the end of this period. The finance officer is not to be removed while in this function except for a grave cause to be assessed by the bishop after he has heard the college of consultors and the finance council. $\S 3$. It is for the finance officer to administer the goods of the diocese under the authority of the bishop in accord with the budget determined by the finance council and, from the income of the diocese, to meet expenses which the bishop or others designated by him have legitimately authorized. $\S 4$. At the end of the year, the finance officer must render an account of receipts and expenditures to the finance council." 
for the purposes described above, the Synod provided for contributions obtained from the monthly collection conducted on the first Sunday of the month (st. 391). Some parishes are fully or partly exempt from those. This matter and the issue of seminaristicum fees and other benefits of diocesan priests are regulated by a separate ordinance, contained in Annex No. 10 to the synodal statutes. ${ }^{19}$

In the Diocese of Opole there are a number of institutions which are capable of self-supporting. The Synod ordered to use the profits generated by these institutions in accordance with their statutes and the diocesan bishop's decision (st. 392).

The normative content of the synodal statutes discussed above is practically identical to the proposals contained in the relevant passage of the Working Paper of the synodal Financial and Investment Commission. In the latter, we also find a list of diocesan institutions and facilities maintained from monthly collections conducted on the first Sunday of the month, institutions financed by the diocese and self-financing institutions. ${ }^{20}$ In addition, the Commission proposed that the profits gained by the diocesan institutions should be used for diocesan purposes, which is not fully reflected in statute 392, discussed above. Another proposal of the Commission concerned the taxation of the Formation House in Nysa and the Formation Centre in Kamień Śląski. They would be taxed according to their usable areas. However, the statutes do not regulate this issue.

\footnotetext{
${ }^{19}$ Annex 10. Ordinance concerning benefits related to the material security of the diocesan institutions and buildings, in Pierwszy Synod Diecezji Opolskiej, 204-8.

${ }^{20} \mathrm{~W}$ drodze do Emaus, 104ff.

A. The diocesan institutions and buildings financed with the monthly collection: the diocesan administration buildings and all departments of the Curia, the building of the Diocesan Curia, the house of the priests employed with the Curia and the Bishop's Court located at ul. Katedralna 1, the Bishops' House at ul. Grunwaldzka 7, Diocesan Museum, Diocesan Formation Centre-ul. Kardynała Bolesława Kominka 1a, and Papal Altar in Góra Świętej Anny (in this case, it was postulated that the Altar be maintained by Franciscans using the offerings donated during diocesan celebrations).

B. Institutions financed by the Diocese: Higher Seminary, Faculty of Theology of the University of Opole, Library, Diocesan House for Retired Priests in Opole and Nysa, House for PriestsProfessors-ul. Kardynała Bolesława Kominka 1a, a nuns house in Grudzice (the Commission requested that this house be maintained by the parish), Caritas of the Diocese of Opole, Radio Plus station, Rectorial Church of Saint Sebastian in Opole (it was argued that this church should be maintained by the cathedral parish where it is located), Diocesan Adoption Centre, Mother and Child House in Grudzice, family counselling, and the clerical aid fund.

C. Self-financing institutions: Wydawnictwo Świętego Krzyża (publishing house), Holy Cross Library, Sanctuary of St Jack in Kamień Śląski, Diocesan Middle and High School in Nysa, Formation House in Nysa.
} 


\section{MATERIAL GOODS OF THE PARISH COMMUNITY}

The Synod appointed the pastor or parish administrator to be the administrator of the parish property, who should act in consultation with the Bishop of Opole in this regard. In particularly important matters, the administrator should ask the opinion of the Parish Pastoral Council, established in accordance with canon $1280 \mathrm{CIC} / 83^{21}$ (st. 393). This estate, as well as the revenue of the parish, should be visibly separated from the property and personal remuneration of the parish priests. The pastor or parish administrator may not kept the assets belonging to the parish in a personal bank account, either his own or belonging to another person. This provision also applies to all administrators of public legal entities under the authority of the Bishop of Opole (st. 394).

The synodal fathers also saw a need for assisting small parishes, especially in their implementation of essential investments. Such aid may take the form of complete or partial exemption from monthly collections (st. 395).

Important matters related to the employment of lay people in church institutions should be regulated by labour law (st. 396). Chaplains are employed in religious houses based on a contract between the congregation and such a priest. This contract should stipulate in detail the responsibilities and rights of the chaplain (st. 397).

In statute 398, the Synod confirms that the primary source of parish funding comes in the form of donations contributed by the faithful. The use of other sources is permitted only after obtaining the consent of the Bishop of Opole - this granted, the pastor is obliged to submit appropriate financial reports to the Diocesan Curia by the end of January each year. Similarly, every collection for the church, organized by the Parish Council or a group of the faithful, must also have the placet the Bishop (st. 399).

All parishes are to keep a current inventory of church property and the presbytery. After the Bishop's visitation, the pastor is obliged to submit these documents to the Diocesan Curia for approval (st. 400).

In the Working Paper of the Financial and Investment Commission, pinpointing the problems to be considered by the parish synodal groups, we find, among others, information that the Diocese of Opole consisted of 396

\footnotetext{
${ }^{21}$ C. $1280 \mathrm{CIC} / 83$ : "Each juridic person is to have its own finance council or at least two counsellors who, according to the norm of the statutes, are to assist the administrator in fulfilling his or her function." In the Diocese of Opole, the "financial" competence is vested in the parish pastoral council, which can have a financial and economic section in its structure. See Annex 5. The statute of the Parish Pastoral Council in the Diocese of Opole, in Pierwszy Synod Diecezji Opolskiej, 184-87.
} 
parishes grouped in 36 deaneries, in which 692 diocesan priests and 129 religious priests worked during the synodal deliberations. There were also 896 religious nuns working in the particular church of Opole. ${ }^{22}$ The Commission addressed the problem of assisting poorer parishes by suggesting, for example, financial support for the purchase of some building materials besides the traditionally accepted ways (being exempted from collections). The Synod allowed such a possibility, as indicated above, but generally keeping the existing solutions. What is more, the Commission proposed to standardize the manner in which offerings made by the faithful during Christmas visitation should be received. Discussed also were donations for the maintenance of the religious cemetery, offerings for prayers for the dead, contributions for church benches and other donations. However, such regulations were not included in the synodal statutes.

\section{IMPLEMENTATION OF SACRED AND CHURCH INVESTMENTS}

Any decision concerning a future investment project should always be scrutinised in terms of the actual needs and financial capacity, and consulted with the Parish Pastoral Council and the Diocesan Curia. The key issue in each investment is its financial aspect and "this should be taken into consideration at every stage of the investment process" (st. 401).

The Synod in Opole pointed out the need for constant care on the part of pastors and the faithful for sacred buildings. New churches should be designed and built to be functional, to facilitate liturgical activities, for the faithful to be actively involved, and to emanate "noble beauty rather than splendour" (st. 402). ${ }^{23}$

${ }^{22} \mathrm{~W}$ drodze do Emaus, 106ff. There were 32 parishes counting up to 500 parishioners, 124 parishes with up to 1000 parishioners, 90 parishes with up to 1,500 parishioners, 49 parishes with up to 2,000 parishioners, 20 parishes with up to 2,500 parishioners, 12 parishes with up to 3,000 parishioners, 5 parishes with up to 3,500 parishioners, 5 parishes with up to 4,000 parishioners, 4 parishes with up to 4,500 parishioners, 7 parishes with up to 5,000 parishioners, 3 parishes with up to 6,000 parishioners, 5 parishes with up to 7,000 parishioners, 8 parishes with up to 8,000 parishioners, 2 parishes with up to 9,000 parishioners, 2 parishes with up to 10,000 parishioners, 1 parish with up to 11,000 parishioners, 4 parishes with up to 13,000 parishioners, 7 parishes with up to 15,000 parishioners, 2 parishes with up to 16,000 parishioners, 3 parishes with up to 17,000 parishioners, and 1 parish with up to 22,000 parishioners.

${ }^{23}$ VATICAN II, Constitutio de sacra liturgia Sacrosanctum Concilium, December 4, 1963, AAS 56 (1964), 97-134; Polish translation in VATICAN II, Konstytucje, dekrety, deklaracje, 48-78, no. 124. 
According to the earlier recommendations of the Episcopal Conference of Poland, endorsed by the Opole Synod, every diocesan priest should sign and adhere to a declaration (contained in Annex No. 24) whereby he undertakes to manage the ecclesiastical property in a manner consistent with the provisions of Polish law and canon law (st. 403).

In an earlier Working Paper of the synodal Financial and Investment Commission, the members of the synodal parish groups dealt with a slightly wider range of issues. While pointing out the need for extensive consultation when considering the possibility of undertaking investment tasks, the whole chain of activities conducted during the construction process was presented in detail: from "the determination of the needs and investment opportunities" to the operation of the complete facility. Of course, this specification was not reflected in the final document, but it could have been helpful at the stage of synodal group consultation. ${ }^{24}$

\section{ANNEXES}

The annexes are an integral part of the legal output of the First Synod of the Diocese of Opole. ${ }^{25}$ Several of them regulate matters related to the management of temporal goods. These will be presented below.

\section{ANNEX 6-STATUTE OF THE FINANCIAL AND ECONOMIC SECTION OF THE PARISH PASTORAL COUNCIL ${ }^{26}$}

The financial and economic section of the Parish Pastoral Council has the competences of the parochial Finance Council. It should consist of at least three members, chaired by the pastor. The purpose of the section is to "assist the pastor in the administration of parish estate in compliance with universal law" (see c. 532 and cc. 1281-1288 CIC/83).

\footnotetext{
${ }^{24}$ W drodze do Emaus, 108-9.

${ }^{25}$ See the introductory section in Pierwszy Synod Diecezji Opolskiej, 12, no. 4.

${ }^{26}$ Aneks 6. Statut sekcji ekonomiczno-gospodarczej Parafialnej Rady Duszpasterskiej, in Pierwszy Synod Diecezji Opolskiej, 188-89.
} 


\section{ANNEX 10-ORDINANCE CONCERNING BENEFITS RELATED TO THE MATERIAL SECURITY OF THE DIOCESAN INSTITUTIONS AND BUILDINGS ${ }^{27}$}

This extensive document consists of five parts. The first one, entitled "Monthly collection contributions," contains information that the collection from the first Sunday of each month firms the basis for the maintenance of diocesan institutions and facilities.

The second part of the annex is entitled "Rules of functioning of the Aid Fund for Priests of the Opole Diocese." It describes how to provide financial assistance to priests who are temporarily unable to work, retired priests, and priests with a disability pension. ${ }^{28}$

The next, third part of the annex, entitled "Fees for the Seminary (seminaristicum)," specifies detailed norms concerning the financing of this institution, as well as partly the Faculty of Theology of Opole University. ${ }^{29}$

\footnotetext{
${ }^{27}$ Aneks 10. Rozporządzenie w sprawie świadczeń związanych z zabezpieczeniem materialnym instytucji i obiektów diecezjalnych, in Pierwszy Synod Diecezji Opolskiej, 204-8. Contributions made during such collections must be paid to the cashier of the Diocesan Curia within 14 days of the collection. However, there are special reliefs for small parishes, especially those which carry the burden of increased expenses for the care of sacred buildings: 1. Parishes with fewer than 400 inhabitants and those with a greater number of churches and fewer than 300 inhabitants per one church were completely exempted from the diocesan collections. 2. Parishes with fewer than 600 inhabitants and those with more churches and fewer than 450 inhabitants per temple were exempted from half of the diocesan collections. 3. In special cases, where a random event or an urgent investment is involved, parishes should apply individually in writing to the Financial and Economic Department of the Curia for an exemption from the fee. It is granted after the Finance Council has been consulted. 4. Simultaneously, the Synod cancelled all previous exemptions from the obligation to transfer assets from monthly collections.

${ }^{28}$ Ibid: Priests - pensioners and disability retirees living outside the Diocesan Priests Retirement Home are to receive a monthly allowance of 350 złoty, but in special cases (severe illness, accident, etc.) it is possible to grant an additional allowance. The fund "is not able to provide pensioners with mass intentions" for priests, and its income is derived from monthly contributions made by priests (from which the said pensioners and disability retirees are exempted, as well as missionaries and those dispatched to do full-time studies). Clerical pensioners and disability retirees are entitled to receive the official diocesan publications, such as Wiadomości Urzędowe Diecezji Opolskiej, Rocznik Diecezji Opolskiej, and Kalendarz Liturgiczny. It was recommended that the sums given to priests in need be transferred to their bank accounts or "transferred in any other agreed way."

${ }^{29}$ Ibid: The priests of the Opole diocese were assigned specific amounts that should be paid monthly to the designated account of the Diocesan Curia, or paid directly to its cashier: 1) pastors of parishes with more than 2,000 faithful -200 złoty. Additionally, if they employ parochial vicars, they are to contribute 50 złoty for each of them; 2) pastors of parishes counting from 1,000 to 2,000 faithful -150 złoty; 3) pastors of parishes with fewer than 1,000 faithful-100 złoty; 4) pastors serving several churches, with more than 300 faithful on average attending one church -50 złoty;
} 
The fourth part of Annex 10 "Other contributions of diocesan and religious priests employed in the Diocese of Opole" contains norms relating to "assurance of the functioning of certain charitable institutions," for which all priests employed in the diocese are to pay contributions in the total amount of 30 złoty. ${ }^{30}$

In the fifth part, entitled "Monthly salaries of pastors and parochial vicars in the Diocese of Opole," we find detailed provisions concerning the maintenance of priests. ${ }^{31}$

\section{ANNEX 24-SYNODAL INSTRUCTION ON THE CONCLUSION OF CONTRACTS CONCERNING MATERIAL GOODS}

In the document, the synodal fathers reminded the pastors, parish administrators and all priests that contracts and activities related to the acquisition, sale, lease of real estate, running a business, establishing a foundation and being its member, taking out loans exceeding one's own six months' income, establishing companies or membership in their management boards must not be concluded and undertaken without the consent and opinion of the Diocesan Curia, in accordance with the provisions of canons 1254-1310 CIC/83. ${ }^{32}$ The annex also contains a template of the "statement on the management of ecclesiastical estate," which should be signed by every priest working in the Diocese of Opole.

5) parochial vicars - 150 złoty; 6) independent academics employed on a full-time basis at a university (not covered by the points listed above) - 200 złoty; 7) assistant professors, lecturers and research assistants employed on a full-time basis at a university (not covered by items 1-5 above100 złoty ; 8) employees of the Diocesan Curia and the Seminary (not covered by points $1-5$ above or who are not explicitly exempt from fees)—100 złoty; 9) religious priests employed in the Diocese of Opole $-50 \%$ of the rate for the diocesan priests listed in points $1-5$. Only retired priests, those with disability pensions, missionaries and those sent to full-time studies were exempt from the fees.

${ }^{30}$ Ibid., 207.

${ }^{31}$ Ibid: "The basis for the maintenance of priests exercising pastoral ministry are mass stipends and remuneration for school teaching. The following monthly salaries are determined for particular groups of priests employed in parishes or in the diocese: 1) parochial vicars receive from the parish the lowest national salary and retain the school salary; with this income they pay taxes and contributions [...]; 2) the lowest pastor's salary is determined as $150 \%$ of the lowest national salary [...]; 3) employees of the Diocesan Curia and the Seminary receive a salary of $110 \%$ of the lowest national salary."

${ }^{32}$ Aneks 24. Instrukcja synodalna w sprawie zawierania umów dotyczących dóbr materialnych, in Pierwszy Synod Diecezji Opolskiej, 292-94. 


\section{ANNEX 25-SYNODAL INSTRUCTION ON THE PROTECTION SACRED MONUMENTS IN CHURCH BUILDINGS ${ }^{33}$}

The Synod declared that all previous ordinances and instructions concerning the protection of works of sacred art were in force. As authorised by the Bishop of Opole, the Diocesan Custodian of Monuments and the Diocesan Museum are in charge of these matters. The works of sacred art in the parish are in the care of the pastor.

It shall not be permissible "under any circumstances" to transfer works of art to other churches and parishes. All such objects shall be photographed. Photographs with a short description should be included in parish inventory books. A copy of the documentation should be sent to the Department of Sacred Art and Monument Conservation of the Diocesan Curia. Additionally, the Synod ordered all pastors and parish administrators to take care to ensure adequate protection of valuable monuments and other valuable objects. Advice on this matter can be obtained from the Diocesan Museum.

\section{ANNEX 27-TEMPLATE FOR A PRIEST'S LAST WILL AND TESTAMENT ${ }^{34}$}

This annex contains the basic information which should be included in a priest's last will. It should include references to God as the Giver of life and priestly vocation, instructions concerning the heir or heirs, indication of the burial place.

It is also instructive to look at the working text intended for consultation with priests only and concerning the "rules of remuneration and maintenance of clergy," which is the subject regulated further on by the provisions of Part $\mathrm{V}$ of Annex 10, as presented above. In this section, forming the second part of the Working Paper of the synodal Financial and Investment Commission, ${ }^{35}$ the main emphasis is placed on the need for the clergy to retain poverty as a condition for effective pastoral work. With regard to pastors' remuneration, it was stated that this is the "remuneration plus the maintenance of the presbytery." It was also argued that "a third [of the remuneration?-A.S.] contributed by parochial vicars from the parish salary towards the maintenance of the presbytery should be used as a contribution to level

\footnotetext{
${ }^{33}$ Aneks 25. Instrukcja synodalna dotycząca zabezpieczania zabytków sakralnych w obiektach kościelnych, in Pierwszy Synod Diecezji Opolskiej, 295-96.

${ }^{34}$ Aneks 27. Wzór testamentu kapłana, in Pierwszy Synod Diecezji Opolskiej, 302-3.

${ }^{35} \mathrm{~W}$ drodze do Emaus, $109-11$.
} 
out the minimum remuneration of the pastors of «small» parishes." Also a vicar's term of office (3 years) was also proposed, especially in the first place of work.

With regard to clerical pensions, it was proposed that retired diocesan priests should be paid a diocesan pension regardless of where they live. A pension fund should also be established to pay pensions based on the amount of contributions made over the last 10 years. A book of perpetual Mass intentions would be created at the Diocesan Priests Retirement Home to help support them with the offerings of the faithful.

\section{CONCLUSION}

According to canon $460 \mathrm{CIC} / 83$, "a diocesan synod is a group of selected priests and other members of the Christian faithful of a particular church who offer assistance to the diocesan bishop for the good of the whole diocesan community." As Helmut J. Sobeczko writes: "The Synod is [...] the joint work of the shepherds and the people. Using biblical language, the synod is listening together to what the Holy Spirit says to a concrete diocesan Church." ${ }^{36}$ The instruction of the Congregation for Bishops on the pastoral ministry of bishops Ecclesiae imago of February 22, 1973 clearly indicates that participation in the Synod and canonical visitations are the main activities in the pastoral ministry of a bishop. ${ }^{37}$

The diocesan bishop exercises legislative authority in an ordinary way, constituting norms of particular law (laws, general decrees, general executive decrees,$^{38}$ or detailed instructions, e.g. concerning the issue of Church temporal goods management [c. 1276, \$2 CIC/83]), or in a solemn manner through active participation in the diocesan synod (c. $381 ;$ c. $391, \S 1$ CIC/83). Then the diocesan bishop is the only legislator, and all the other members of the synodal congregation have only an advisory vote. ${ }^{39}$

\footnotetext{
36 “Wykład ks. prof. dr. hab. Helmuta J. Sobeczki wygłoszony w czasie uroczystej sesji plenarnej inaugurującej Pierwszy Synod Diecezji Opolskiej," Biuletyn Synodu Diecezji Opolskiej 1 (2002): 34.

${ }^{37}$ See CONGREgATION FOR Bishops, Directorium de pastorali ministerio Episcoporum Ecclesiae imago, February 22, 1973 (Typis Polyglottis Vaticanis, 1973); Polish translation in Posoborowe prawodawstwo kościelne, ed. E. Sztafrowski (Warszawa: Akademia Teologii Katolickiej, 1973), 6/1:21-324, no. 162.

${ }^{38}$ See c. 29 , and c. 391 in connection with c. $13, \S 1$, c. 29 , and c. 31 CIC/83.

${ }^{39}$ D. WALENCIK, "Regulacje prawne dotyczące spraw majątkowych i potrzeb finansowych instytucji kościelnych," in II Polski Synod Plenarny a synody diecezjalne, ed. J. Krukowski, M. Sitarz, and A. Pastwa (Lublin: Towarzystwo Naukowe KUL, 2015), 208.
} 
As Dariusz Walencik writes: "The diocesan synod is an instrument with which the diocesan bishop urges the observance of those canonical norms which are the most relevant for the diocese's circumstances; it regulates the issues entrusted to him, and introduces a discipline common to all the particular Churches. Therefore, rather than establishing new norms, the diocesan bishop should effect the reception of universal law to the diocesan legislation and/or insist on the observance of canon law, if necessary." ${ }^{40}$ That same author points to some anti-juridical tendencies can be seen when the final documents of some contemporary synods referred to as "pastoral" are being drafted. ${ }^{41}$ This often results in the underdevelopment of the norms of particular law (the failure to included the section "Temporal goods of the Church" in the synodal statutes, literal repetition of the norms of universal canon law, or a very succinct treatment of the subject of temporal goods administration).

What is, then, the output of the First Synod of the Opole Diocese seen against that background? In the 17 statutes concerning temporal goods of the particular church of Opole, there are legal norms associated with the administration of the diocesan and parish property and with the execution of investments in church and sacred buildings. The first annex contains the statute of the financial and economic section of the Parish Pastoral Council. The second, very extensive, contains norms concerning benefits connected with material security of the diocesan institutions and facilities (the annex regulates the principles of monthly collections for the diocese, forming the basis for the maintenance of diocesan institutions and facilities, the functioning of the Aid Fund for the Priests of Opole Diocese, seminaristicum fees, and provision for the functioning of some charitable institutions). The next annex contains the synodal instruction on the conclusion of contracts for material goods, the next one contains the synodal instruction on the protection of sacred monuments in church buildings; and the last one provides the model of a priestly last will.

When evaluating the scope of these regulations, we should note some degree of fragmentariness of this approach to the subject of temporal goods. ${ }^{42}$ For example, in the final document of the First Synod of the Diocese of Opole we will find practically no norms concerning the diocesan finance

\footnotetext{
${ }^{40}$ Ibid., 210.

${ }^{41}$ Ibid., 214.

${ }^{42}$ On the indications as to the obligatory content of synodal resolutions with respect to temporal goods, see WALENCIK, Regulacje prawny, 217-18.
} 
council (st. 390 merely mentions a "financial council" and makes reference to canon 494, $\$ 3 \mathrm{CIC} / 83$, which addresses mainly the tasks of the diocesan finance officer, cooperating with the Finance Council). Likewise, there is no model statute or rules for conducting the works. Annex 6, on the other hand, defines the competences of the financial and economic section, which has the competences of the Parish Pastoral Council.

The final document lacks regulations regarding clerical remuneration (although draft solutions were provided in Part II of the Working Paper of the synod Financial and Investment Commission intended to be discussed by priests); it does not specify rules for the retirement of priests (pension, disability pension, sick leave), the statute and rules of the house for retired priests, as well as the rules for the distribution of iura stolae. There is no indication of the purposes for which the offerings collected during bination and trination should be given. No list is provided of acts of extraordinary administration for juridical persons subordinate to the authority of the diocesan bishop (see c. 1281, §1 CIC/83), as well as the detailed conditions for the establishment and acceptance of foundations by ecclesiastical juridical persons and clerics (see c. 1304, \$2 CIC/83). Among the rules for the administration of temporal goods, there are no regulations concerning the management of cemeteries (see cc. 1276, §2, and $1180 \mathrm{CIC} / 83$ ). The annexes, however, provide a template for the priestly last will, a regulation which is probably not the most important for the practice of managing ecclesiastical property in the diocese.

The deficiencies shown above undoubtedly affect the manner in which the particular canon law of the Diocese of Opole is legislated, but they do not significantly impair the functioning of the relevant church institutions. The diocese seems to be managed efficiently, the necessary legal norms do exist, but outside the synodal legislation. A certain "anti-juridicality" of the First Synod of the Diocese of Opole with regard to administration of temporal goods may cause a canonist lawyer examining the synodal final document to experience some dissonance. This may even call into question the real point of developing synodal final documents which do not fully regulate the most important spheres of the functioning of a particular Church. However, it must also be admitted that the synodal legislator, represented by the diocesan bishop, has the right to establish such particular norms as it deems appropriate and necessary. 


\section{BIBLIOGRAPHY}

\section{SOURCES OF LAW}

Catechismus Catholicae Ecclesiae. Vatican City: Libreria Editrice Vaticana, 1997. Polish translation in Katechizm Kościoła Katolickiego, $2^{\text {nd }}$ ed. Poznań: Pallottinum, 2012.

Codex Iuris Canonici auctoritate Ioannis Pauli PP. II promulgatus, January 25, 1983. AAS 75 (1983), pars II, 1-317. Polish translation in Kodeks Prawa Kanonicznego, translation approved by the Polish Episcopal Conference. Poznań: Pallottinum, 1984.

Dekret ustanawiający skład osobowy Komisji ds. Finansowo-Inwestycyjnych Pierwszego Synodu Diecezji Opolskiej [Decree establishing the composition of the Financial and Investment Commission of the First Synod of the Diocese of Opole]. Biuletyn Synodu Diecezji Opolskiej 1 (2002): 32.

Dekret zwołujący Pierwszy Synod Diecezji Opolskiej i ogłaszający jego otwarcie z 19 marca 2002 r. [Decree of 19 March 2002 convening the First Synod of the Diocese of Opole and announcing its opening], No. 207/002/A. In Pierwszy Synod Diecezji Opolskiej (2002-2005). Statuty i Aneksy, 311-13. Opole: Wydawnictwo Św. Krzyża, 2005.

Instrukcja synodalna dotycząca zabezpieczania zabytków sakralnych w obiektach kościelnych [Synodal instruction on the protection of sacred monuments in church buildings]. In Pierwszy Synod Diecezji Opolskiej (2002-2005). Statuty i Aneksy, 295-96. Opole: Wydawnictwo Św. Krzyża, 2005.

Instrukcja synodalna w sprawie zawierania umów dotyczących dóbr materialnych [Synodal instruction on the conclusion of contracts concerning material goods]. In Pierwszy Synod Diecezji Opolskiej (2002-2005). Statuty i Aneksy, 292-94. Opole: Wydawnictwo Św. Krzyża, 2005.

John PaUl II. List apostolski Novo millennio ineunte. Kraków: Wydawnictwo Pallottinum, 2001.

Rozporządzenie $\mathrm{w}$ sprawie świadczeń związanych $\mathrm{z}$ zabezpieczeniem materialnym instytucji i obiektów diecezjalnych [Ordinance concerning benefits related to the material security of the diocesan institutions and buildings]. In Pierwszy Synod Diecezji Opolskiej (2002-2005). Statuty i Aneksy, 204-8. Opole: Wydawnictwo Św. Krzyża, 2005.

CONGREgATION FOR Bishops. Directorium de pastorali ministerio Episcoporum Ecclesiae imago, February 22, 1973. Typis Polyglottis Vaticanis, 1973. Polish translation in Posoborowe prawodawstwo kościelne, edited by Edward Sztafrowski, 6/1:21-324. Warszawa: Akademia Teologii Katolickiej, 1973.

Vatican Council II. Constitutio de sacra liturgia Sacrosanctum Concilium, December 4, 1963. AAS 56 (1964), 97-134. Polish translation in Konstytucje, dekrety, deklaracje, tekst polski, nowe ttumaczenie, 48-78. Poznań: Pallottinum, 2002.

Vatican Council II. Decretum de pastorali episcoporum munere in Ecclesia Christus Dominus, October 28, 1965. AAS 58 (1966), 673-96. Polish translation in Konstytucje, dekrety, deklaracje, tekst polski, nowe ttumaczenie, 236-58. Poznań: Pallottinum, 2002.

Vatican Council II. Decretum de presbyterorum ministerio et vita Presbyterorum ordinis, December 7, 1965. AAS 58 (1966), 991-1024. Polish translation in Konstytucje, dekrety, deklaracje, tekst polski, nowe ttumaczenie, 478-508. Poznań: Pallottinum, 2002.

Statut parafialnej rady duszpasterskiej w Diecezji Opolskiej [Statute of the parish pastoral council in the Diocese of Opole]. In Pierwszy Synod Diecezji Opolskiej (2002-2005). Statuty i Aneksy, 184-87. Opole: Wydawnictwo Św. Krzyża, 2005.

Statut sekcji ekonomiczno-gospodarczej Parafialnej Rady Duszpasterskiej [Statue of the financial and economic section of the Parish Pastoral Council]. In Pierwszy Synod Diecezji Opolskiej (2002-2005). Statuty i Aneksy, 188-9. Opole: Wydawnictwo Św. Krzyża, 2005. 
Wzór testamentu kapłana [Template for a priest's last will and testament]. In Pierwszy Synod Diecezji Opolskiej (2002-2005). Statuty i Aneksy, 302-3. Opole: Wydawnictwo Św. Krzyża, 2005.

\section{LITERATURE}

MikoŁajec, Józef. "Duszpasterstwo rodzin w uchwałach Pierwszego Synodu Diecezji Opolskiej." Warszawskie Studia Pastoralne 3 (2006): 56-69.

SZYMAŃSKI, Andrzej. Ks. Bp dr Franciszek Jop-prawodawca i organizator diecezji opolskiej. Opole: Wydawnictwo Uniwersytetu Opolskiego, 2007.

SZYMAŃSKI, Andrzej. "Nauczanie i wychowanie chrześcijańskie w parafii w świetle uchwał I Synodu Diecezji Opolskiej." In Wychowanie religijne i moralne, edited by Ryszard Sztychmiller and Mieczysław Różański, 67-74. Olsztyn: Wydział Prawa i Administracji Uniwersytetu Warmińsko-Mazurskiego, 2015.

SzYMAŃSKI, Andrzej. "Pierwszy Synod Diecezji Opolskiej 2002-2005.” Studia Teologiczno-Historyczne Ślaska Opolskiego 28 (2008): 377-404.

$W$ drodze do Emaus. Dokumenty robocze Komisji Synodalnych. Opole: Wydawnictwo Św. Krzyża, 2003.

WALENCIK, Dariusz. "Regulacje prawne dotyczące spraw majątkowych i potrzeb finansowych instytucji kościelnych.” In II Polski Synod Plenarny a synody diecezjalne, edited by Józef Krukowski, Mirosław Sitarz, and Andrzej Pastwa, 199-219. Lublin: Towarzystwo Naukowe KUL, 2015.

"Wykład ks. prof. dr. hab. Helmuta J. Sobeczki wygłoszony w czasie uroczystej sesji plenarnej inaugurującej Pierwszy Synod Diecezji Opolskiej.” Biuletyn Synodu Diecezji Opolskiej 1 (2002): 33-39.

\section{THE CHURCH'S TEMPORAL GOODS IN THE WORK AND THE FINAL DOCUMENT DRAFTED BY THE FIRST SYNOD OF THE DIOCESE OF OPOLE}

\section{Summary}

In the article, a reflection is made on the legal regulations developed by the First Synod of the Diocese of Opole, concerning the management of temporal goods of the Diocese. The study presents the content of 17 statutes and 5 annexes (as well as considering earlier studies produced by one of the synodal working commissions, intended to be discussed by the parish synodal groups), and reflects on the completeness of the legal treatment of this vital yet complex area of ecclesiastical life. The solutions adopted by the Synod should be considered incomplete, but the synodal legislator, that is the diocesan bishop, has the right to enact such particular norms as he deems appropriate and necessary.

Key words: Opole; synod; temporal goods.

\section{Translated by Tomasz Patkowski}

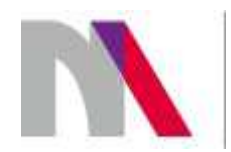

The preparation of the English version of Roczniki Nauk Prawnych (Annals of Iuridical Sciences) and its publication in electronic databases was financed under contract no. 836/PDUN/2018 from the resources of the Minister of Science and Higher Education for the popularization of science. 